\title{
PENGARUH MEDIA PUZZLE TERHADAP HASIL BELAJAR SISWA PADA KARAKTERISTIK HIDUP HEWAN DI KELAS IV SDN 106814 TEMBUNG KECAMATAN PERCUT SEI TUAN
}

\author{
Andina Halimsyah Rambe, Nurul Delilah Harahap \\ Surel: andinahalimsyahrambe@uinsu.ac.id
}

\begin{abstract}
This study aims to determine student learning outcomes using puzzle media in Class IV 106814 Tembung students. In this study, the researchers found a problem where there were some students who did not get a score below the KKM, problems were found when conducting initial observations at SDN 106814 Tembung, especially in science subjects. The research was conducted with 4th grade elementary school students on science subjects at SDN 106814 Tembung with the aim of fixing the problems that researchers found and it is hoped that students will be able to develop abilities using puzzle media during the teaching and learning process. This type of research uses a preexperimental technique with a one group test-post test model, which only involves one class.
\end{abstract}

Keywords: Learning Outcomes, Science, Media Puzzle

\begin{abstract}
ABSTRAK
Penelitian ini bertujuan untuk mengetahui hasil belajar siswa dengan menggunakan media puzzle pada Siswa Kelas IV 106814 Tembung. Pada penelitian ini peneliti menemukan permasalahan yang dimana terdapat beberapa siswa yang kurang memperoleh nilai dibawah KKM, permasalahan yang ditemukan ketika melakukan observasi awal di SDN 106814 Tembung khususnya pada mata pelajaran IPA. Penelitian dilakukan dengan siswa SD kelas 4 pada mata pelajaran IPA di SDN 106814 Tembung memiliki tujuan untuk memperbaiki permasalahan yang peneliti temukan dan diharapkan siswa mampu memilki kemampuan yang berkembang dengan menggunakan media puzzle pada saat proses belajar mengajar berlangsung. Jenis penelitian ini melakukan teknik pra-eksperimen dengan model one group test-post test, yaitu hanya melibatkan satu kelas.
\end{abstract}

Kata Kunci : Hasil Belajar, IPA, Media Puzzle

\section{PENDAHULUAN}

Proses pembelajaran yang terjadi di zaman sekarang ini seharusnya tidak lagi terpaku pada buku cetak untuk tujuan sumber belajar. Guru sebagai pemimpin di kelas seharusnya mampu menciptakan suatu metode atau model pembelajaran yang dimana harus sesuai dan sejalan dengan materi pelajaran dan juga baik untuk menumbuhkan kepercayaan diri terhadap peserta didik, membuat siswa agar termotivasi, merangsang siswa agar semangat untuk belajar, dan meningkatkan kemampuan 
Andina Halimsyah Rambe, Nurul Delilah Harahap : Pengaruh Media ...

berpikir kritis terhadap memajukan pemahaman suatu konsep terhadap siswa. Melalui hasil belajar yang telah dilakukan terhadap peserta didik, baik itu bagus atau tidaknya kegiatan proses belajar berlangsung adalah proses kognitif yang dilakukan oleh guru kepada siswanya. Menurut fakta yang didapat dari observasi di SDN 106814 Tembung, dapat dilihat mengenai hasil belajar siswa tidak sebanding dengan apa yang semestinya diharapkan, terutama pada mata pelajaran IPA.

Berdasarkan hasil nilai peserta didik pada kelas IV SDN 106814 SDN 106814 Tembung Kecamatan Percut Sei Tuan Kabupaten Deli Serdang dengan diperkuat pada daftar nilai siswa pada mata pelajaran IPA dengan 15 orang siswa ada 9 siswa yang mendapat nilai dibawah $\mathrm{KKM}$ dengan interval berupa 41-68 yakni interval nilai 40-75. Beberapa siswa yang tuntas dengan pencapaian nilai tertinggi adalah 85 dan jumlah siswa yang siswa yang tuntas hanya 6 orang. Hal ini semakin diperkuat dengan kenyataan bahwa lebih dari separuh siswa semester IV SDN 106814 Tembung yang tidak memenuhi nilai KKM dinyatakan tidak memenuhi standar KKM pada mata pelajaran IPA revisi. Hal ini tidak terlepas dari Permasalahan yang dilakukan guru mengenai proses belajar mengajar bahwa rendahnya kegiatan guru untuk mengoptimalkan serta kreativitas untuk memanfaatkan media pembelajaran pada saat proses belajar berlangsung. Media merupakan suatu alat komunikasi agar guru dan siswa saling berkomunikasi menyampaikan pesan pembelajaran yang dimengerti dan yang tidak dimengerti. Mata pelajaran IPA yang merupakan salah satu mata pelajaran yang sangat membutuhkan media pembelajaran tentunya penggunaan media harus sesuai dengan materi pembelajaran serta memperhatikan penggunaan media baik itu minat siswa terhadap media ketika penyampaian pembelajaran berlangsung dan kondisi media. Kondisi media disesuaikan agar siswa memahami materi pembelajaran karena banyak siswa yang umurnya masih tingkat usia tahap bermain dan belajar.

Di era globalisasi ini siswa banyak yang banyak bermain game tetapi tidak memanfaatkannya dengan baik. Banyak dari mereka bermain game hanya untuk tujuan hiburan yang tidak mengandung unsur pendidikan. Penting bagi anak-anak untuk belajar sambil bermain. Seorang peneliti pendidikan bernama Peter Kline (Nugrahani, 2007:36) menyatakan bahwa belajar dalam suasana yang nyaman itu efektif. Kegiatan seperti ini merupakan keadaan yang sangat membutuhkan media pembelajaran, dengan adanya media pembelajaran peserta didik akan mendapat semangat dorongan ketika belajar sehingga peserta didik diharapkan menghasilkan respon yang baik ketika proses belajar berlangsung. Pengalaman yang diberikan oleh siswa bukan hanya permainan saja melainkan pengetahuan untuk memahami 
pembelajaran yang diberikan serta menstimulasi pemahamannya mengenai pembelajaran dan rasa pengetahuannya. Maka dari itu media pembelajaran yang berbasis pembelajaran sambil bermain sangat dibutuhkan terutama dalam penyampaian materi pembelajaran IPA. Berkaitan dengan permasalahan diatas penulis memulai suatu tindakan penelitian terkait media pembelajaran yang digunakan untuk melakukan kegiatan proses belajar mengajar terutama pada mata pelajaran IPA di kelas IV SD dengan materi pembelajarannya adalah karakteristik hidup hewan. Dengan media yang akan digunakan ketika saat penelitian adalah media puzzle.

Permainan puzzle merupakan permainan yang dilakukan dengan menyusun beberapa potongan gambar yang kemudian digabungkan atau disatukan akan membentuk sebuah gambar yang lengkap. Dengan adanya media puzzle yang akan digunakan tentunya memiliki keterkaitan dengan materi karakteristik hidup hewan di kelas IV SD pada mata pembelajaran IPA. Penggunaan media yang efisien dan inovatif ini diharapkan mampu untuk memberikan hasil yang bagus terhadap siswa.

\section{METODE PENELITIAN}

Peneliti menggunakan jenis penelitian rancangan yang dimana penelitian rancangan ini mencakup hanya satu kelompok atau kelas serta dilakukan penelitian pra dan pasca uji ketika kegiatan penelitian berlangsung serta untuk pengujian diberikan tes awal (pretest) sebelum diberikan perlakuan, setelah diberikan perlakuan barulah memberikan tes akhir (posttest). Penelitian ini diprioritaskan pada hasil belajar siswa terhadap mata pembelajaran IPA, khususnya untuk materi karakteristik hidup hewan di kelas IV SD pada mata pelajaran IPA dengan menggunakan media puzzle.

Penelitian yang dilakukan di SDN 106814 pada siswa kelas IV Kecamatan Percut Sei Tuan Kabupaten Deli Serdang, dengan menggunakan teknik penelitian adalah sampling jenuh dan yang menjadi sampel dari peneliti lakukan adalah siswa kelas IV untuk jumlah 10 orang, yang dimana untuk siswa perempuan ada 6 orang sedangkan siswa laki-laki terdiri dari 4 siswa. Peneliti melakukan teknik pengumpulan data dengan menggunakan tiga teknik, yaitu dokumentasi, tes, dan observasi. Tahapan penelitian yang peneliti lakukan terdiri dari menggunakan tiga tahap, tahap pertama adalah tahap persiapan, tahap selanjutnya adalah tahap pelaksanaan, dan tahap terakhir adalah analisis data hasil dan pelaporan. Tahap persiapan adalah tahap yang mempunyai tahap dengan mengidentifikasi masalah, Kemudian tahap penyediaan bahan yang akan disampaikan meliputi identifikasi masalah, pemilihan bahan yang akan digunakan untuk penelitian, kemudian pengurusan izin sekolah yang akan digunakan untuk melakukan penelitian dan pengembangan RPP yang akan digunakan. Tahap 
Andina Halimsyah Rambe, Nurul Delilah Harahap : Pengaruh Media ...

pelaksanaan, yaitu tahap dimana melakukan pelaksanaan kegiatan dengan melaksanakan kegiatan pembelajaran serta memberikan tes awal dan tes akhir. Kemudian sampai pada tahap analisis data.Tahap ini merupakan tahap menganalisis dan mengumpulkan hasil pengolahan data, serta membuat laporan berupa hasil dan laporan. Teknologi analisis data adalah teknologi yang terdiri dari analisis statistik dan analisis penalaran deskriptif. Penilaian dengan teknik analisis statistik inferensial, yaitu dengan menguji hipotesis. Teknik pengujian yang digunakan yaitu uji-t dengan taraf signifikansi $\alpha$ $=0,05$. Teknik penilain dari analisis statistik deskriptif untuk memuat data hasil belajar pengetahuan siswa dengan pretest dan posttest siswa. Lakukan uji prasyarat terlebih dahulu, kemudian lakukan uji hipotesis terlebih dahulu, lakukan uji prasyarat yaitu menggunakan standar uji untuk uji normalitas, yaitu jika X2 hitung tabel $\mathrm{X} 2, \mathrm{dk}=(\mathrm{k}-1)$ berada pada taraf signifikansi $=0,05$ atau 5\% Maka data dianggap terdistribusi normal.

\section{HASIL PENELITIAN DAN PEMBAHASAN}

Penelitian dilakukan selama dua kali pertemuan yang dimana, pada pertemuan pertama pendidik melakukan pemberian materi kepada peserta didik tanpa menggunakan media puzzle, pada serta dilakukan pemberian pretest, yang dimana pada pertemuan kedua ini pendidik memberikan materi dengan menerapkan penggunaan media puzzle serta pemberian posttest. Hasil analisis penelitian dilakukan dengan hasil analisis yang menggunakan statistika deskriptif. Setelah peneliti melakukan penelitian dapat diuraikan mengenai hasil analisis statistika deskriptif nilai rata-rata dari skor hasil belajar siswa materi pelajaran IPA tentang karakteristik hidup hewan dengan tidak menggunakan mediapuzzle (pretest) adalah 60 dari skor ideal 100. Skor tertinggi didapatkan dengan nilai 90 dan skor terendah yang dicapai siswa adalah 60. Jika nilai hasil belajar siswa pada pembelajaran IPA tidak menggunakan media, maka dibagi menjadi lima kategori:

Tabel 1. Persentase Skor Hasil Belajar Siswa (Pretest) IPA Kelas IV SDN 106814 Tembung

\begin{tabular}{|c|c|c|c|c|}
\hline No. & Skor & Kategori & Frekuensi & Persantase \% \\
\hline 1. & $0-60$ & Sangat rendah & 3 & $30 \%$ \\
\hline 2. & $61-70$ & Rendah & 2 & $20 \%$ \\
\hline 3. & $71-80$ & Sedang & 2 & $20 \%$ \\
\hline 4. & $81-90$ & Tinggi & 2 & $20 \%$ \\
\hline 5. & $91-100$ & Sangat tinggi & 1 & $10 \%$ \\
\hline \multicolumn{3}{|c|}{ Jumlah } & 10 & $100 \%$ \\
\hline
\end{tabular}

Dari skor dan kategori yang telah dideskripsikan hasil belajar 
siswa pada pembelajaran karektristik makhluk hidup hewan didapatkan dengan rata-rata nilai adalah (postetst) 75,5 dengan skor ideal adalah 100, maka diperoleh distribusi skor frekuensi dan persentase yang disajikan untuk tes Pretest pada Tabel 1. Skor tertinggi siswa yang didapatkan, yaitu 95 dengan skor terendah dicapai dengan nilai 60 . Apabila pada penilaian hasil belajar siswa tersebut dikelompokkan dengan menggunakan lima kategori, hasil perolehan distribusi dan persentase skor dapat dilihat pada tabel 2 .

Tabel 2. Persentase Skor Hasil Belajar Siswa (Posttest) IPA Kelas IV SDN 106814 Tembung

\begin{tabular}{l|l|l|l|l}
\hline No. & Skor & Kategori & Frekuensi & Persantase\% \\
\hline 1. & $0-60$ & Sangat rendah & 0 & $0 \%$ \\
\hline 2. & $61-70$ & Rendah & 1 & $10 \%$ \\
\hline 3. & $71-80$ & Sedang & 2 & $20 \%$ \\
\hline 4. & $81-90$ & Tinggi & 3 & $30 \%$ \\
\hline 5. & $91-100$ & Sangat tinggi & 4 & $40 \%$ \\
\hline Jumlah & & $\mathbf{1 0}$ & $\mathbf{1 0 0 \%}$ \\
\hline
\end{tabular}

\section{Pembahasan}

Dengan adanya media puzzle membuat siswa lebih memahami materi karakteristik hidup hewan siswa juga mampu melakukannya dengan mandiri maupun secara berkelompok. Pada hasil pretest siswa rata-rata hasil belajar siswa adalah 60 yang terdiri dari $30 \%$ sangat rendah, $20 \%$ rendah, $20 \%$ sedang, dan $20 \%$ sedang. Untuk skor tinggi dan skor sangat tinggi, persentasenya adalah 10\%. Dengan menggunakan persentase yang telah dijumlahkan dapat diketahui bahwa hasil belajar siswa dalam mempelajari ciri-ciri hewan hidup sebelum menggunakan media pembelajaran dapat dikatakan berada pada taraf rendah. Pada posttest, rata-rata skor prestasi belajar siswa dalam pembelajaran ciri-ciri hewan hidup adalah 88,5, dengan skor rendah $10 \%$, skor sedang $20 \%$, skor tinggi $30 \%$, dan skor sangat tinggi. skor $40 \%$. Penggunaan media yang diberikan menunjukkan hasil yang meningkat secara signifikan. Pembelajaran ciri-ciri hewan hidup dengan pengguna media puzzle memiliki implikasi yang relevan karena dapat meningkatkan hasil belajar siswa pada mata pelajaran IPA Kelas IV. Bersantailah saat mereka sedang belajar. Tidak hanya itu, siswa juga dapat membangun keterampilan sosialnya sendiri melalui media puzzle saat merakit potongan menggunakan foto binatang yang berlangsung melalui diskusi.

\section{SIMPULAN}

\begin{tabular}{llcr}
\multicolumn{2}{c}{ Berdasarkan hasil } & survey \\
yang dilakukan di & SDN & 106814 \\
Tembung Kecamatan & Percut & Seituan
\end{tabular}


Andina Halimsyah Rambe, Nurul Delilah Harahap : Pengaruh Media ...

Kabupaten Deriseldan, Karakteristik

Kehidupan Hewan Kelas IV

Menggunakan Media Puzzle Media Puzzle memiliki konsekuensi dan dampak penting terhadap hasil belajar siswa.Saya sampai pada kesimpulan memberi. IPA Kelas IV mata pelajaran terkait. Ini mengacu pada data yang dilakukan dengan melakukan survei.

\section{DAFTAR RUJUKAN}

Nugrahani, R.. 2007. Media Pembelajaran Berbasis Visual Berbentuk Permainan Ular Tangga untuk Meningkatkan Kualitas Belajar Mengajar di Sekolah Dasar. Skripsi. Universitas Negeri Semarang, Semarang.

Anas, Nirwana. 2019. Konsep Dasar IPA, Medan : FITK UINSU

Arafat Maulana Lubis. 2018. Pembelajaran PPKn Teori Pengajaran Abad 21 di SD/MI.
Yogyakarta: Samudra Biru.

Fahrurrozi dan Syukrul Hamdi. 2017. Metode Pembelajaran

Matematika. Nusa Tenggara Barat: Universitas Hamzanwadi Press.

Tambunan Hamongan, Marsangkap Silitonga, Uli Basa Sidabutar 2020. Blended Learning dengan Ragam Gaya Belajar. Medan: Yayasan Kita Menulis.

Isrok'atun dan Amelia Rosmala.

2018. Model-Model

Pembelajaran Matematika.

Jakarta: Bumi Aksara.

Kartika Nurul dan Inul Zuhdi. 2018.

Pengaruh Penerapan Probing-

Prompting Learning Terhadap

Hasil Belajar IPS Siswa Kelas 3

SD Negeri Lakardowo. Jurnal

Penelitian Pendidikan Guru

Sekolah Dasar. 6(8), 1-10.

Purwanto, M.N. 1998. Metodologi

Pengajaran Di Sekolah Dasar.

Jakarta: Rosda Jayapura 